\author{
MARINA MATIĆ \\ Independent scientific Researcher \\ Belgrade \\ maticmarina@yahoo.com
}

\title{
BISHOP SAVATIJE LJUBIBRATIĆ UNDER THE AUSPICES OF THE REPUBLIC OF VENICE (1687-1716)*
}

\begin{abstract}
Using unpublished archive material, the text eliminates certain doubts regarding the personality of the Herzegovinian Bishop Savatije Ljubibratić. It sheds light on several decades of dilemmas about his Herzegovinian bishopric seat. Furthermore, it defines the time and circumstances of his moving to Boka Kotorska more precisely and more comprehensively, as well as his activities under the auspices of the Republic of Venice.

Keywords: Bishop Savatije Ljubibratić, Piva, Venetian rule, Orthodox Christian identity, Boka Kotorska, 17th and 18th century.
\end{abstract}

\section{Trebinje or Piva}

$\mathrm{T}$ The northwestern part of Boka (Risan, Herceg-Novi) was historically and geographically connected with Herzegovina. Since Herceg-Novi remained the last Turkish stronghold in Boka, its conquering was of primary strategic and political importance for the Venetians. With its conquest, the Venetians would have power over the entire Boka, ${ }^{1}$ opening their way to penetrating Herzegovina as well. ${ }^{2}$ For realizing their plans, they used Serbian clans in Herzegovina, raising their hopes that they would thus be liberated from Turkish oppression and be under a kind of Christian dominion. ${ }^{3}$ The

\footnotetext{
* This text is an original scientific paper and result of several years of investigation (field and archive) in the area of Boka Kotorska (Herceg-Novi) for the preparation of a doctoral dissertation defended in 2015.

${ }^{1}$ Ever since the $15^{\text {th }}$ century Boka Kotorska was divided into the southeastern (Venetian) and northwestern (Turkish) part. Thus Turkey controlled the entrance into the Boka Kotorska Bay and was a constant threat to the Venetian positions inside the Bay (Perast, Kotor).

${ }^{2}$ The objective of the Venetians was to conquer the strategically important Trebinje, further opening their way to conquering Popovo, Zažablje, all the way to Opuzen. They would thus take possession of the entire Lower Herzegovina and the entire Herzegovina by taking over Gacko (Musić 1988: 171-172).

${ }^{3}$ In order to accept the Venetian dominion, the clans insisted on several conditions: to receive regular payments for the heads of clans, approval for forming one squad per clan, and to be given self-government after the model
} 
Venetians finally succeeded in conquering Herceg-Novi during the Morean War (16841699), more precisely on September 30 1687, on the Day of St. Jerome. ${ }^{4}$ Following that event, the city became an important religious and political stronghold to Herzegovinian Bishop Savatije and later to Bishop Stefan Ljubibratić. Bishop Savatije himself, as we are about to see, participated in many endeavors and battles in the Morean War on the Venetian side.

Although literature, without any specified sources, often states that Bishop Savatije came to Herceg-Novi from Trebinje (Tvrdoš), where his bishopric seat had allegedly been, no proof to support such claims has been found until now. ${ }^{5}$ There are, however, many sources indicating that, until his arrival to Herceg-Novi, Savatije's seat was in the Piva Monastery. An interesting note from 1683, written on a Gospel in the Savina Monastery, mentions a certain Savatije as the prior of the Piva Monastery. If it were related to later Bishop Savatije Ljubibratić, it would be one of the first mentions of his name, as well as his connection with the Piva Monastery. ${ }^{6}$ We find more precise information in the reports of Provveditore Korner after the Venetian conquest of Herceg-Novi. Korner informs his government on November 221687 from Herceg-Novi about the arrival of the Nikšić clan with a Herzegovinian bishop dwelling in Piva. ${ }^{7}$ This is also directly confirmed by the dispatch of Provveditore Erizo dated September 1 1692, enclosing the letter of Bishop Savatije from the Piva Monastery. In the letter dated August 191692 Savatije writes about the arrival of hayduks to Piva. He states that many people of Piva had left with them, that they killed many Turks and took a huge booty. ${ }^{8}$ The report of Governor Ivan Burović sent to associate provveditore on November 241692 had a similar content, stating that Bishop Savatije came from the upper areas to Kotor and informed him that enemy troops were located around Pljevlja, Prijepolje and Mileševa. ${ }^{9}$ A letter from vicar Bolica dated December 1 1689, translated by L. Tomanović, also mentioned the Bishop of Piva staying in Herceg-Novi, who could replace Metropolitan Visarion Borilović in case he would accept to, further to the Patriarch's order, leave Cetinje and go to Peć. ${ }^{10}$ Furthermore, the Bishop

\footnotetext{
of the Privileges of the Paštrović clan.

${ }^{4}$ Stanojević 1970: 336-337.

${ }^{5}$ Mijušković 1953: 266; Ruvarac 1901: 22; Petranović 1859: 158; et al. The General Paper of Tvrdoš and Savina (Opšti list) states a list of metropolitans who had their seat in the Trebinje Monastery including the names of Savatije and Stefan Ljubibratić (Đordan 1885: 31-32). The unreliability of these texts is shown by the fact that it is known for certain that Stefan Ljubibratić never had his seat in Trebinje, but was a bishop in Herceg-Novi, Dragović and later in Kostajnica.

${ }^{6}$ Stojanović 1923: 182-183 (no. 7000). Such an assumption should be taken with plenty of reserve because the icon of Virgin with Archangels (created by Dimitrije Daskal, 1680/81) in the Cathedral Church in Risan has an inscription stating that Savatije was signed two years earlier as the Bishop of Herzegovina (Vujičić 1980: 215).

${ }^{7}$ Musić 1988: 149.

${ }^{8}$ Archive of the Serbian Academy of Sciences and Arts, Belgrade, Heritage of Jovan Tomić, no. 8711-XI/i-6 (hereinafter ASANU, ZJT).

${ }^{9}$ Vukčević 1998: 104.

${ }^{10}$ Tomanović 1931: 107. The translation of the same document, published in Vukčević 1998: 55, calls this bishop the bishop of the coastal areas. The translator probably relied on the unfounded popular opinion that Savatije had his seat in the Trebinje Monastery, therefore it was illogical to call him the Bishop of Piva. Furthermore, there is a possibility that he automatically took over Savatije's later title. At the time this document was created Savatije was, without an exception, called the Bishop of Herzegovina, of Zahumlje or of Piva. He was called the
} 
of Zahumlje and Herzegovina Gerasim Popović, who replaced Savatije when he moved to Herceg-Novi, had his bishopric seat in the Piva Monastery. ${ }^{11}$ Perhaps the most direct confirmation that Savatije's seat was in Piva is given by the Venetian Cadaster for HercegNovi from 1690, where Savatije was enlisted as Vescovo di Piva, with the list of land granted to him in the surrounding area (Fig. 1). ${ }^{12}$

Accordingly, Savatije's bishopric seat before his arrival to Herceg-Novi was most probably in the Piva Monastery. The claims without any specified sources that his seat was in the Trebinje Monastery (Tvrdoš) brought several decades of confusion about the otherwise also complicated period of Serbian history (the late $17^{\text {th }}$ century), full of wars, migrations, and continuous turbulences around strategically important strongholds and borders.

\section{Reestablishing of Bishop Savatije}

The Orthodox Christian clergy had a very important function in preserving the faith and integrity of the people in the complicated circumstances of migrations and a physical separation of the Serbian corpus. Knowing that in wartime circumstances not much could be achieved without the support of the local Orthodox population of Boka and Dalmatia, Venetian authorities invested a great effort in winning the Orthodox clergy on their side. The Orthodox clergy, however, saw the possibility of getting certain privileges and status in order to preserve their identity in the absence of a church organization and under the foreign rule.

Already since the conquering of Herceg-Novi in 1687 we noticed that Herzegovinian Bishop Savatije often visited this area and was very engaged in different missions on the Venetian side. He played a significant role in the implementation of military cooperation between the Serbian population from Herzegovina and the Venetians, as well as the operation of their migration to Boka. ${ }^{13}$ In that aspect, there was a long, deeply rooted confusion, seen in different authors. Literature states that Bishop Savatije moved the monks from the Tvrdoš Monastery in 1693 to Herceg-Novi and the Savina Monastery after the Venetians destroyed Tvrdoš. ${ }^{14}$ Such data was not known until now. The document dated

Bishop of the coastal areas and Dalmatia only much later.

${ }^{11}$ Stojanović 1903: 34, 90-91 (no. 2268, no. 2603). This is also confirmed by a document from a later period, dated March 141742 stating that a bishop from Piva arrived to Trebinje (for a kind of a usual visit of his bishopric area) and that priests from the surrounding areas came to visit him [Archive of Herceg-Novi, Herceg-Novi, Political and Administrative Venetian Archive (1689-1797), f. 321, 283 (1)] (hereinafter AH, PUMA).

12 AH, PUMA, Catastico delle terre, case e molini di Castel Nuovo 1990-92, book 2, fol. 217.

${ }^{13}$ Thus, on December 101687 in Perast, in the presence of Bishop Savatije, the Herzegovinian clan heads took an oath to the general provveditore that they would fulfil all provisions of the agreement on populating Herzegovina and fighting against the Ottomans. Such united clans made a population of four to five thousand people, thereof 700 under arms, who would protect this area well. According to the agreement, they also had an obligation to support 300 people in the permanent guard appointed by the Venetians for defense against Turkish surprise attacks. For all stated services the clans would receive 200 sacks of wheat for the winter. In his report to the Senate General Provveditore Korner especially emphasizes his skillfulness in achieving such cost saving for the Republic (Vukčević 1998: 10-12).

${ }^{14}$ Medaković 1978: 14; Crnogorčević 1901: 5; Popović 1909: 12; Zloković 1971: 8. 
September 1693, which the refugee monks from Tvrdoš received from the Venetian authorities, stating aid in money and biscuit when they arrived to Herceg-Novi only mentions the prior of Tvrdoš, Teofil Radulović, who led their migration, and not Bishop Savatije Ljubibratić. ${ }^{15}$

As a reputable man, he was the safety factor for the Venetians, someone they could count on to gather and lead the people in case of need. Savatije personally states about his wartime engagement: I came at the beginning of the battle in Novi, with my regiment of Christians. ${ }^{16}$ Savatije wrote the letter to Živo Grbičić on August 271691 from HercegNovi. We further discover that he was also fighting under the auspices of the serene Principle in Gacko, Knin, Trebinje and Ljubomir. ${ }^{17}$ The fact that Savatije was already feeling entirely at home in Herceg-Novi and its surroundings can also be seen from his letter addressed to Archbishop of Bar Andrija Zmajević, dated December 29 1691, hurrying from Herceg-Novi to the village of Morinj, near Risan, on business. ${ }^{18}$ Also speaking in favor of it is the fact that the Venetian Cadaster of Herceg-Novi from 1689 (preliminary Cadaster which got its final form a year later, in 1690) already states that the Bishop of Herzegovina was dwelling in Herceg-Novi with six monks (Vescovo d'Hercegovina con calogeri sei, in tutto sette) and that they were granted land in that area (Podi, Sasović, Kazimir, Brajkovina, Topla). ${ }^{19}$ Furthermore, the mentioned Venetian Cadaster from 1690 enlists the Herzegovinian bishop as a Venetian subject, with the mentioned significant piece of land in the area of Herceg-Novi. ${ }^{20}$ He received it from the Venetian authorities in order to support himself while staying in that area, but also as a reward for his engagement on the Venetian side in the Morean War and a thoughtful Venetian gesture of obligating him for further endeavors on their side. ${ }^{21}$ In 1690 Savatije had in his possession land in the villages of Podi, Sasović, Kazimir and Brajkovina, with a total area of 9 campos, 5.5 quarrata and 106

\footnotetext{
15 Šerović 1959: 577.

${ }^{16}$ Mijušković 1953: 267.

17 Ibid. 267.

${ }^{18}$ Giannelli 1955: 75-76.

${ }^{19}$ ASANU, ZJT, no. 8711-XV/16 (Catastico di Castel Nuovo 1689), 12.

${ }^{20}$ AH, PUMA, Catastico..., књ. 2, 217.

${ }^{21}$ We should keep in mind that, after the departure of Patriarch Arsenije III, Venetians intensified the pressure on Serbian bishops in the area of Herzegovina and Montenegro to put them under their rule. Their objective was to prevent the imposed Patriarch of Peć Kalinik I, who also worked ardently on winning over, for his own interests, bishops from the Venetian zones of interest. (Tomić 1990: 221; Id. 1906, 142-143). Since Kalinik I was acceptable neither to Venetians nor the Orthodox Christian clergy, there was intensive work on his suppression. In that aspect, it is interesting to mention an intriguing copy of a letter written by Bishop Savatije Ljubibratić in August 1702, discovering the consideration of Savatije's appointing for the Patriarch of Peć (if the letter is not a forgery). In the letter addressed to General Provveditore Alvise Mocenigo Savatije states that he was elected at the church Council in Hungary with the blessing of Patriarch Arsenije III and upon the order of Provveditore of Kotor Ferige Badoero to replace Arsenije III in the seat of Patriarch of Peć because he couldn't return anymore (Avviso poi Vostra Eccellenza per ordine d'Eccellentissimo Signor Ferigo Badoer Provveditore Estraordinario di Cattaro, come per volontà di Dio, e per giudizio della Chiesa, e con la benedizione del Patriarca Arsenio di Pech, di Servia e di Bulgaria, il quale ora si ritrova in Ungheria, e nella congregazione delle altre persone ecclesiastiche e Laiche, delle Provicnie di Servia e di Bulgaria, e dei Vescovi, che nel detto Paese si ritrovano di Rito Greco; mi elessero coi voti, e per ordine che fossi Patriarca di Pech sostituito al sudetto Patriarca Arsenio, poich'esso non può più ritornare alla sua residenza, per essersi seco partito numeroso popolo Christiano, ASANU, ZJT, no. 8711/VI - a/8c).
} 
tavolas. ${ }^{22}$ He had also in his possession land in Topla of 10 campos, 10.5 quarrata and 106 tavolas. ${ }^{23}$ In his letter dated October 281708 addressed to General Provveditore Vendramin, Savatije clearly states that he left his bishopric in Herzegovina in the Ottoman state twenty years ago and moved to live under the auspices of the Republic. ${ }^{24}$ The report of the Republic of Venice legal councilors dated September 151710 also speaks in favor of the presupposition that Savatije retreated from the Herzegovinian bishopric to Herceg-Novi at the beginning of the war and that he had chosen to live as a subject of the Republic. ${ }^{25}$ One letter written by General Provveditore Daniel Dolphin in 1736 mentions that Serbian Bishop Savatije came from Herzegovina and that he had been living in Herceg-Novi since $1687 .{ }^{26}$

It is known for certain that the Venetian state treasury granted regular income to Savatije as the Bishop of Herzegovina on June 29 1695. ${ }^{27}$ The payments were cancelled in a certain period but the ducal from October 271710 confirmed them. ${ }^{28}$ A document dated March 231707 permanently granted Savatije a house in Topla, land and vineyards in Topla (8c: 12q: 504t), Đenovići (3c: 12q: 195t) and Podi (5c: 3q: 27t), with the obligation to pay a monthly fee to the state in accordance with public regulations. ${ }^{29}$ The state thus took into consideration his great merits for the Republic, as well as great efforts and investments to make goods from the infertile land with his own resources. ${ }^{30}$ Besides his residence in Topla, Savatije had a small Chapel of St. Nicholas and made a bridge in the vicinity leading to Igalo and further towards Sutorina. ${ }^{31}$ The Cadasters from 1690 and 1704 did not have the Chapel of St. Nicholas enlisted. We learn about it only from the 1758 census. $^{32}$

The aforementioned statements convincingly indicate that Savatije often or regularly stayed in the area of Herceg-Novi after the Venetian conquering of the city (1687). Certainly, until the appointment of the new Bishop of Zahumlje, Gerasim Popović, ${ }^{33}$ he also occasionally visited his official bishopric seat in Piva. This is confirmed by the mentioned reports he sent from Piva to Venetian provveditores.

\footnotetext{
${ }^{22}$ These are padovano campos. Each campo covered $3862.27 \mathrm{~m}^{2}$, approximately 40 ares, and a quarrata was one quarter of a campo.

${ }^{23}$ AH, PUMA, Catastico..., b. 2, 217.

${ }^{24}$ ASANU, ZJT, no. 8711/XXII-e/6 (Unisco alla supplicazione mia humilissima il vanto glorioso d'esser il suddito rassegnato di questo pubblico Augusto Dionisio, abbandonata già venti anni sono la nostra Diocesi dell'Erzegovina in Stato Ottomano e solo aspetto di vivere sotto le ali del mio Serenissimo Principe e respirare ne suoi stati le aree fortunate...).

25 Jačov 1981: 71.

${ }^{26}$ Milaš 1899: 238.

${ }^{27}$ Ibid. 89

${ }^{28}$ Ibid. 89.

${ }^{29}$ State Archive of Kotor, Kotor, Political and Administrative Venetian Archive (1684-1797), L. XXIII, 235-236 (hereinafter DAK, PUMA).

${ }^{30}$ DAK, PUMA, Ibid. 235-236.

${ }^{31}$ Popović 1924: 128.

${ }^{32}$ Stanojević 1956: 34. It is interesting that the Church of St. George in Topla, the first Orthodox church built after the Venetian conquering of Herceg-Novi on the foundations of a destroyed mosque, was also never mentioned before the 1758 census.

${ }^{33}$ There are different statements about the time Gerasim Popović took over the Bishopric of Herzegovina. Some state the year was 1692 (Tomić 1906: 144) and others say it was 1694 (Vuković 1996: 125).
} 


\section{Activities and Significance of Bishop Savatije}

During his entire stay under the auspices of the Republic of Venice Bishop Savatije persistently attempted to establish jurisdiction and order, both in the newly populated territory of Boka and later in Dalmatia. ${ }^{34}$ He also strived to receive an official ducal from the Venetian authorities about his jurisdiction over those lands. ${ }^{35}$ On several occasions during 1710/11 he sent requests for granting such powers. ${ }^{36}$ Correspondingly, we notice that he changed his title from Bishop of Herzegovina to gradually adding bishop of Dalmatia (coastal areas). ${ }^{37}$ Under different circumstances perhaps he would be able to make part of his jurisdiction official with the Venetian authorities, but since the spring of 1711 a new important factor appeared at the Dalmatian border: a probability of an uprising of Herzegovinian and Montenegrin clans against Turkey with a big possibility to spread the battles over the border to the areas of the Republic. Before such a threat the Venetian authorities were not willing to make such a big step and grant such wide powers to an Orthodox bishop. The Archbishop of Zadar Priuli and the Bishop of Makarska Bjanković devotedly worked on strengthening such a stand. ${ }^{38}$

The uprising did break out in 1711 and the representatives of the church were in the center of attention, primarily Metropolitan of Cetinje Danilo as well as Herzegovinian bishops Gerasim Popović and Savatije Ljubibratić. When Russia entered the war against Turkey in the autumn of 1710 Russian Emperor Peter the Great also turned to Balkan Christians. ${ }^{39}$ On that occasion he sent Colonel Mihailo Miloradović to Montenegro with the task to incite a wider uprising in the Balkans in order to make the war easier for Russia and provoke as much turmoil as possible in Turkey. ${ }^{40}$ Knowing from the directions of his senior

\footnotetext{
${ }^{34}$ The issue was especially actualized after the departure of Bishop Nikodim Busović from Dalmatia (after 1702/1703) (Jačov 1981: 70)

${ }^{35}$ Bogović 1982: 56-60. Savatije began special activities in that aspect in 1708, when he convinced the Venetian authorities that he was elected the Bishop of Dalmatia at the Serbian Council in Krušedol that same year, instead of Busović (Jačov 1981: 71; ASANU, ZJT, no. 8711/XXII-e/6; no. 8711/XXII-e/8). The veracity of such Savatije's jurisdictions was never confirmed and they are sometimes stated as incorrect [Šorgić 2011: 702-703]. However, he visited Dalmatia at least once (ASANU, ZJT, no. 8711/VIII-f/29; Milaš 1899: 110, 118).

${ }^{36}$ Jačov 1981: 70-72; ASANU, ZJT, no. 8711/VIII-f/41.

${ }^{37}$ The earliest confirmed mention of Savatije's title was on the icon Virgin with Archangels from the Church of St. Peter and Paul in Risan (1680/81), designating Savatije as the Bishop of Herzegovina (Vujičić 1980: 215). Mentioned in several texts as the Semi-Zahumlje and Semi-Herzegovinian Metropolitan, originating from Piva and the family of Ruđić. Such texts are from 1693, 1694, and 1702 and also mention that he became a monk in the Trebinje Monastery [Stojanović 1902: 462, 464 (no. 1983, no. 1994); Id. 1903: 1, 4, 29 (no. 2090, no. 2105, no. 2240)]. An inscription on a book from 1702, in private ownership, commonly mentions Savatije as the Zahumlje and Semi-Herzegovinian Metropolitan, but emphasizes that he later also became the Metropolitan of Dalmatia [Id. 1902: 335 (no. 1306)]. The imperial gate of the Small Savina Church holds an inscription from 1703 under the icon of Archangel Gabriel, mentioning Savatije as the Metropolitan of Herzegovina and Coastal Areas [Ibid: 6 (no. 2114)]. Therefore, according to the said facts, Savatije began adding the title of the Metropolitan of Dalmatia or Coastal Areas to his title of the Metropolitan of Herzegovina only from 1702/3. The time corresponds with the prosecution of the Bishop of Dalmatia Busović by the Catholic bishops (Jačov 1983: 180) and his leaving Dalmatia and departing to Mt. Athos (Id. 1981: 70).

${ }^{38}$ Ibid. 1981: 72; ASANU, ZJT, no. 8711/VIII-f/41.

${ }^{39}$ Stanojević 1955: 61 .

${ }^{40}$ Tomić 1920: 161.
} 
court advisor Sava Vladislavić, a Herzegovinian, that the Montenegrin and Herzegovinian clans had been aspiring for a long time to be freed from Turkish oppression, he believed that he would find support among them. Russia directly promised to liberate Christians from the Turkish oppression, therefore Montenegrins, Brdovians and Herzegovinians joined its liberation war. ${ }^{41}$ The leader of the uprising, Colonel Miloradović, also expected significant support from the people of Boka Kotorska in his endeavors. Thus, on July 181711 he sent a declaration to the people of Novi and Risan to join the fights. ${ }^{42}$ Venetians were cautious to prevent the movement from spreading onto their Orthodox Christian subjects, thus forbidding the sales of gunpowder and lead to Montenegrins on their territory. ${ }^{43}$

Although no proof was found about Savatije's direct involvement in the 1711 Uprising ${ }^{44}$ several documents do indicate the possibility of his indirect participation in those events. A Venetian document dated June 141712 indicates that Savatije's secretary was accused of cooperating with Colonel Miloradović and was consequently removed from his position. ${ }^{45}$ Such confusions were also created by the famous Miloradović's letter (if it is not a forgery) granting Savatije for his contributions (without any precise details about them) the property of Mustafa Ćatović, a Turk from Trebinje (Fig. 2) ${ }^{46}$ The property included houses and a shop in Trebinje as well as a house, a mill, gardens and vineyards in the village of Pridvorice. Such a gift from Miloradović was hardly possible because the battles against Turks in Herzegovina at the very beginning were neither large nor powerful. There was especially no mention of any specific or permanent results because after the first Turkish attack on Montenegro (1712) the rebel forces in Herzegovina gave up on further fighting and made a deal with the Turks. ${ }^{47}$ A Venetian report dated October 281711 states that the rebels succeeded in seizing a great loot and desolated the land around Trebinje but did not manage to stay there long. ${ }^{48}$ There is a certain possibility that this letter to Metropolitan Savatije Ljubibratić was addressed in that very short period in the autumn of 1711 or spring of 1712 when guerilla actions were again performed in Herzegovina and when Miloradović was personally present there. A letter with such contents and the seal of the Russian army colonel possibly had the objective to initiate and gain a more open support of the rebels by Bishop Savatije and through him most of the population of Boka. They needed help more than anything, especially after the unsuccessful attacks of rebels on Turkish fortifications

\footnotetext{
${ }^{41}$ Stanojević, Vasić 1975: 251-252.

42 Stanojević 1955: 66.

${ }^{43}$ Stanojević 1955: 66.

44 There are opinions that Savatije rejected all cooperation with Russian agents and the Metropolitan of Cetinje Danilo regarding the preparation of the uprising of Serbs in Boka (Šorgić 2011: 702-703).

45 ASANU, ZJT, no. 8711/VIII-f/48 (... Ha creduto Il Senato pronto che nell'uso della benemerita attenzione da voi contribuita per tener nelle sollevazioni già insorte per opera di Ribelli suditti del Turco in Albania imune da qualunque molesto incidente il nostro confine e li riguardi importanti del pubblico interesse, siete andato praticando contro la persona del Segretario del Vescovo Greco Savatie reso soppresso per la causa accennate d'aperta intelligenza col Miloradovich, capo principale di ribelli medesimi).

${ }^{46}$ Novaković 1884: 103-104; Savina Monastery Archive, Herceg-Novi, Folder with Decrees, inv. no. 151 (hereinafter AMS, F).

${ }^{47}$ Stanojević, Vasić 1975: 265.

${ }^{48}$ Stanojević 1955: 70.
} 
Gacko and Nikšić ${ }^{49}$ and the preparations of Ahmed-Pasha, a Bosnian vizier for an expedition to punish Montenegro in the spring of $1712 .{ }^{50}$ When the expedition started both Miloradović and the Metropolitan of Cetinje Danile found sanctuary in Grbalj and the hinterland of Herceg-Novi and from there attempted to give the last resistance to the Bosnian vizier as well as to gain support of Venetian subjects in those areas. ${ }^{51}$ Bishop Savatije, however, could not do much under a constant supervision of Venetian authorities but he indirectly did help Miloradović. He gave him a certain financial support. The decree of the Russian Senate dated June 111722 mentions that Miloradović personally admitted that he was in great financial problems and that in spring 1712 he was forced to take a loan of 700 golden Venetian ducats from the Metropolitan of Herzegovina Savatije. ${ }^{52}$ It further states that Savatije prepared the money for the restoration of the Trebinje Monastery but when he saw the penetration of enemy forces and bloodshed he gave the money to Miloradović. ${ }^{53}$

Savatije's activities were numerous. He participated in the ordination of Sava Očinić for the Metropolitan of Cetinje after the death of Visarion Borilović on November 271694 in Herceg-Novi. ${ }^{54}$ It is interesting that shortly before that the Montenegrin Senate (Zbor) unanimously elected Savatije as the successor of Visarion. This is testified by a letter written by Montenegrin dukes and clan heads to Provveditore Marchelo on May $41694 .{ }^{55}$ Savatije's presence was also noticed at the Synod in Dunaszekcső in June 1700, when Danilo was ordained the Metropolitan of Cetinje. ${ }^{56}$ On July 181705 he returned from his pilgrimage to the Holy Land together with his nephew, deacon Stefan. He made a statement about this trip, noted in a sanitary report made upon his return to Herceg-Novi. ${ }^{57}$

A literary inscription in the Church of Holy Salvation in Topla testifies that the Cathedral Church was raised while the Bishop's seat was in Herceg-Novi. ${ }^{58}$ According to the said inscription the construction of the church began on April 21709 on the land granted by a certain Staniša Tomov and consecrated by Savatije on March 21 1713. ${ }^{59}$ The 1704 Cadaster confirms that the stated Staniša Tomov did have property in Topla. ${ }^{60}$ Besides this information, the literary inscription reveals a series of data about the construction of the church, costs, prices, donors.

Bishop Savatije was also often a counselor in civil litigations. ${ }^{61}$ Provveditore De Pino, however, forbade members of the clergy to be advocates in civil litigations. ${ }^{62}$ Furthermore,

\footnotetext{
${ }^{49}$ Tomić 1920: 166-167.

${ }^{50}$ Ibid. 172.

${ }^{51}$ Tomić 1920: 185-186, 189-190.

52 Narochnicky, Petrovič 1984: 65-66.

${ }^{53}$ Ibid. 66.

${ }^{54}$ Stojanović 1902: 463 (no. 1985); Vuković 1996: 430.

${ }^{55}$ Ljubić 1878: 24-25.

56 Vitković 1873: 5-8.

57 Šerović 1965: 137-140.

${ }^{58}$ Petranović 1868: 144-148.

${ }^{59}$ Ibid. 144-148.

${ }^{60}$ Stanojević 1983: 27-33.

${ }^{61}$ AH, PUMA, f. 25, 448, 449, 450, f. 31, 57...

${ }^{62}$ AH, PUMA, f. 18, 44-45.
} 
Savatije tirelessly worked in increasing the property of the monastery and bishopric by receiving them as gifts both from Venetian authorities and believers. It was clear to him that, without a significant financial income, he could not sufficiently strengthen the order and church in an unfavorable setting. We learn from Venetian documents, for example, that he bought land in Meljine from the Kuvelja sisters in 1706, which he later transferred to the Savina Monastery, ${ }^{63}$ or that he bought real estate including houses, land and shops from the Milošević brothers in Topla in $1712 .{ }^{64}$ On several occasions we discovered land and other property gifted by people to Bishop Savatije or the Savina Monastery. ${ }^{65}$

It is clear that the role and dedication of Bishop Savatije Ljubibratic were enormous and had multiple meanings in this area. He participated in military endeavors on the Venetian side in the Morean War for the liberation of Herzegovina and Boka from Turks. He was a great support to Venetians in strategically populating very important border territories in Herzegovina and Boka, desolated after the departure of Turks. He tirelessly fought for gaining episcopal jurisdiction over the areas of Dalmatia and Boka, as well as for establishing a church organization. This battle, after Savatije's death and banishing of Bishop Stefan Ljubibratić, would be continued by priors and archimandrites of Savina until the end of the Venetian rule (1797). Bishop Savatije understood the significance of establishing an organization and order of the local Orthodox community as well as its role in preserving the Serbian Orthodox identity under the foreign rule. Thus he devotedly worked on the restoration and construction of churches in the newly populated areas of Boka Kotorska, strongholds in the given circumstances with a special importance and role of the revival of the Savina Monastery, a Zion of the Orthodox people of Boka and further.

We can find information about Savatije's death in the 1713 Typicon, given as a gift to the Metropolitan of Cetinje Danilo during his visit to Russia. In 1715 Metropolitan Danilo gifted it to the Church of Holy Salvation in Topla. ${ }^{66}$ In that Typicon Stefan Ljubibratic noted: ... at that time, His Grace Savatije, Metropolitan of Zahumlje, passed away and was honorably buried at the Church of Assumption in Savina, where monks of the Trebinje Monastery dwell, with their prior Georgio of Trebinje. Written by Hadži Stefan, a student of the passed away gentleman: in the year of our lord 1716 in the month of April $23 .{ }^{67}$

\footnotetext{
${ }^{63}$ AH, PUMA, L. T. No. IV - no. 9, 14 (1).

${ }^{64}$ AH, PUMA, f. 44, 27, 28, 42, 43, 45, 47.

${ }^{65}$ AH, PUMA, f. 31,88 , f. 44, 47, L. T. No. IV/9, $14,28 .$.

${ }^{66}$ Pestorić 2005: 282 (no. 306).

${ }^{67} . . . v$ to vreme prestavi se preosvešteni Savatie, mitropolit zah(u)mski i pogrebe se mn(o)gia č(a)stno pri hramu Uspenia Presvetie Bogorodici v Savini, i dež prebivaiot monasi monastira Trebinska, pri igumenu toe obiteli kir Georgio Trebinskomu. Črtah az mnaši hadži Stefan, učenik prestavlaša gospodina: v leto Božia Slova, 1716. $m(e) s(e) c a$ april $v 23$ [Archive of the Assumption Church in Herceg-Novi (Cathedral Church in Topla), HercegNovi, Typicon 1713, (hereinafter AVCHN)].
} 


\section{REFERENCES:}

Unpublished sources:

Archive of the Assumption Church in Herceg-Novi (Cathedral Church in Topla), Herceg-Novi, Typicon 1713 (AVCHN).

Archive of the Savina Monastery, Herceg-Novi, Folder with Decrees (AMS, F.).

Archive of the Serbian Academy of Sciences and Arts, Belgrade, Heritage of Jovan Tomić, no. 8711 (ASANU, ZJT).

Archive of Herceg-Novi, Herceg-Novi, Political and Administrative Venetian Archive (1689-1797), Catastico delle terre, case e molini di Castel Nuovo 1990-92, book 2; L. T. (Libro Terminazioni); f. (fascicul) (AH, PUMA).

State Archive of Kotor, Kotor, Political and Administrative Venetian Archive (1684-1797), L. (Libro) XXIII (DAK, PUMA).

\section{References:}

Bogović, M. Katolička crkva i pravoslavlje u Dalmaciji za vrijeme mletačke vladavine, Zagreb: Kršćanska sadašnjost, 1982.

Vitković, G. „Spomenici iz budimskog i peštanskog arhiva“, Glasnik Srpskog učenog društva, 2, 1873. (Serbian Cyrillic)

Vujičić, R. „Ikonopisna djela Dimitrija Daskala u Risnu“, Boka, 12, 1980, 213-221. (Serbian Cyrillic)

Vuković, S. (episkop šumadijski), Srpski jerarsi od devetog do dvadesetog veka, Beograd-PodgoricaKragujevac: Evro, Unireks, Kalenić, 1996. (Serbian Cyrillic)

Vukčević, D. K. (prir.) Crna Gora - Izveštaji mletačkih providura 1687-1735, Podgorica: CID, 1998. (Serbian Cyrillic)

Giannelli, C. „Lettere del Patriarca di Peć Arsenio III e del Vescovo Savatije all' Arcivescovo di Antivari Andrea Zmajević“", Orientalia christiana periodica, 21 (1-2), 1955, 75-77.

Đordan, J. „Bilješke i podaci za istoriju crkve i književnost“, Šematizam pravoslavne eparhije Bokokotorske, Dubrovačke i Spičanske za godinu 1885, 1885, 31-32. (Serbian Cyrillic)

Zloković, M. „Mletačka uprava u Herceg-Novom“, Boka, 3, 1971, 5-37. (Serbian Cyrillic)

Jačov, M. „Pravni savetnici pri mletačkoj vladi o pravoslavnima u Dalmaciji i Boki Kotorskoj“, Spomenik, 122, 1981, 61-90. (Serbian Cyrillic)

. Spisi tajnog vatikanskog arhiva XVI-XVIII veka, Beograd: SANU, 1983. (Serbian Cyrillic)

Ljubić, Š. „Rukovet jugoslovenskih listina - Crnogorsko-mletačke listine“, Starine JAZU, 10, 1878, $1-43$.

Medaković, D. Manastir Savina - Velika crkva, riznica, rukopisi, Beograd: Filozofski fakultet, 1978. (Serbian Cyrillic)

Mijušković, S. „Jedan dokumenat o učestvovanju mitropolita Savatije Ljubibratića u bitkama Morejskog rata“, Istorijski zapisi, 1, 1953, 266-269. (Serbian Cyrillic)

Milaš, N. Spisi o istoriji pravoslavne crkve u dalmatinsko-istrijskom vladičanstvu od XV-XIX veka, Zadar: Tipografija S. Artale, 1899. (Serbian Cyrillic)

Musić, S. Izveštaji generalnog providura Dalmacije i Albanije Kornera o zauzimanju Herceg-Novog 1687. godine, Herceg-Novi: Arhiv Herceg Novog, Zavičajni muzej, Gradska biblioteka, 1988. (Serbian Cyrillic)

Narochnicky, A. L. i Petrovič N. (prir.) Politicheskie i kulturnije otnoshenija Rossii s jugoslavyanskimi zemlyami v XVIII v. - dokumenty, Moskva: Nauka, 1984. (Russian Cyrillic)

Novaković, S. „Trebiñe, Tvrdoš i Savina“, Starine JAZU, 16, 1884, 97-107.

Pestorić, V. „Popis knjižnog fonda pravoslavnih crkava na području Opštine Herceg-Novi“, Boka, 25, 2005, 213-348. (Serbian Cyrillic) 
Petranović, G. „Letopis pravoslavne crkve u Dalmaciji - O pravoslavnim dalmatinskim episkopima“, Srbsko-dalmatinskiŭ magazinb za godinu 1854-1859,1859, 152-159. (Serbian Cyrillic) . „Ljetopis Pravoslavne Crkve u Dalmaciji - U Topli, crkva Parohiяlna“, Srbsko-dalmatinskiǔ magazins za godinu 1868, 1868, 127-158. (Serbian Cyrillic)

Popović, T. K. Manastir Savina - istorijske crtice, Kotor: Jovan Sekulović, 1909. (Serbian Cyrillic)

Popović, T. K. Herceg-Novi - istorijske bilješke 1382-1797, Herceg-Novi: Orjen, 1924. (Serbian Cyrillic)

Ruvarac, I. O humskim episkopima i hercegovačkim mitropolitima, Mostar: Paher i Kisić, 1901. (Serbian Cyrillic)

Stanojević, G. Crna Gora u doba vladike Danila, Cetinje: Istoriski institut NR Crne Gore, 1955. (Serbian Cyrillic)

. „Nekoliko statističkih podataka o Boki Kotorskoj iz sredine XVIII stoleća“, Spomenik, 105, 1956, 27-39. (Serbian Cyrillic) . Jugoslovenske zemlje u mletačko-turskim ratovima XVI-XVIII veka, Beograd: Istorijski institut, 1970. (Serbian Cyrillic)

. Katastri Herceg-Novog i Risna iz 1704. godine, Beograd: SANU, 1983. (Serbian Cyrillic)

Stanojević, G. i Vasić M., Istorija Crne Gore, I/3, Titograd: Redakcija za istoriju Crne Gore, 1975. (Serbian Cyrillic)

Stojanović, Lj. Stari srpski zapisi i natpisi I, II, IV, Beograd: Srpska kraljevska akademija, 1902, 1903, 1923. (Serbian Cyrillic)

Tomanović, L. „Patrijarh Arsenije III i mletačka vlast 1689“, Glasnik Istorijskog društva u Novom Sadu, 4, 1931, 103-108. (Serbian Cyrillic)

Tomić, J. „Patrijarh Arsenije III Crnojević prema Mlečićima i Ćesaru 1685-1695“, Glas SKA, 70, 1906, 65-161. (Serbian Cyrillic) . „Turski pohod na Crnu Goru 1712. god.“, Glas SKA, 96, 1920, 153-196. (Serbian Cyrillic) . Srbi u velikoj seobi - Deset godina iz istorije srpskog naroda i crkve pod Turcima (16831693), Beograd: Prosveta, 1990. (Serbian Cyrillic)

Crnogorčević, M. Manastir Savina u Boci Kotorskoj, Beograd: T. K. Naumović i drug, 1901. (Serbian Cyrillic)

Šerović, P. D. „Odluka generalnog providura Dolfina o izdavanju dvopeka kaluđerima manastira Trebinja (Tvrdoša) prebjeglim na mletačku teritoriju“, Istorijski zapisi, 2, 1959, 576-577. (Serbian Cyrillic)

. „Zapisnik o jednoj sanitarnoj proceduri u lazaretu u Herceg-Novome iz god. 1705“, Godišnjak Pomorskog muzeja u Kotoru, 13, 1965, 137-140. (Serbian Cyrillic)

Šorgić, M. „Savatije Ljubibratić“, Srpski biografski rečnik 5 (Kv-Mao), Novi Sad: Matica srpska, 2011. (Serbian Cyrillic) 


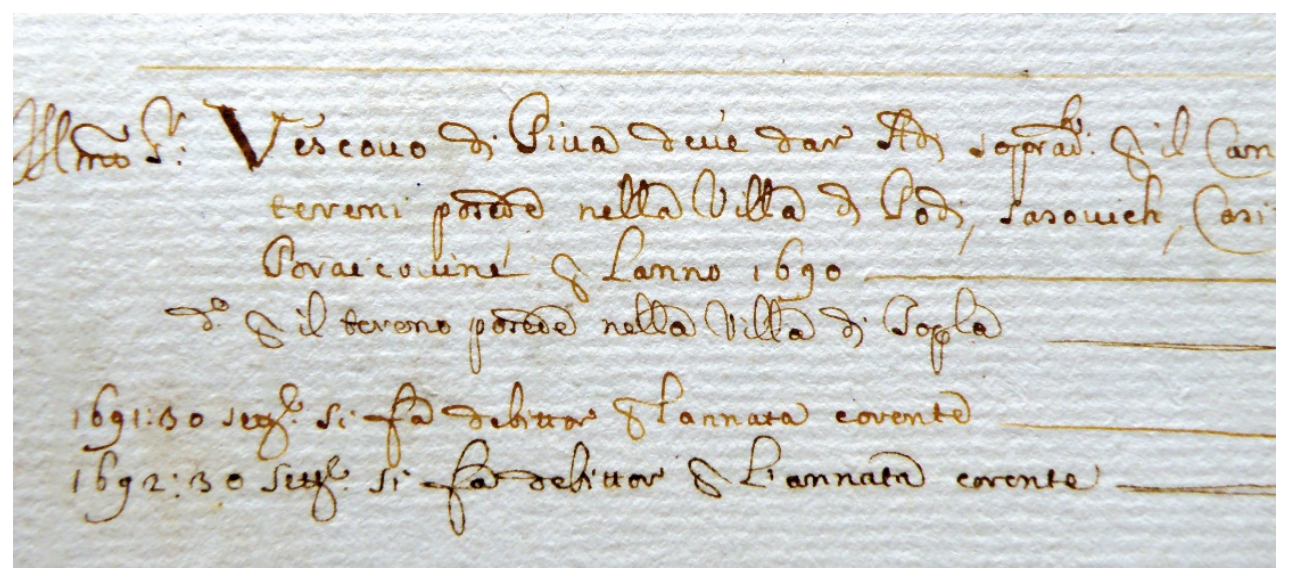

Fig. 1 - Cadaster of Herceg-Novi from 1690

(Catastico delle terre, case e molini di Castel Nuovo 1990-92, књ. 2)

(detail with the title of Bishop Savatije, fol. 217). 


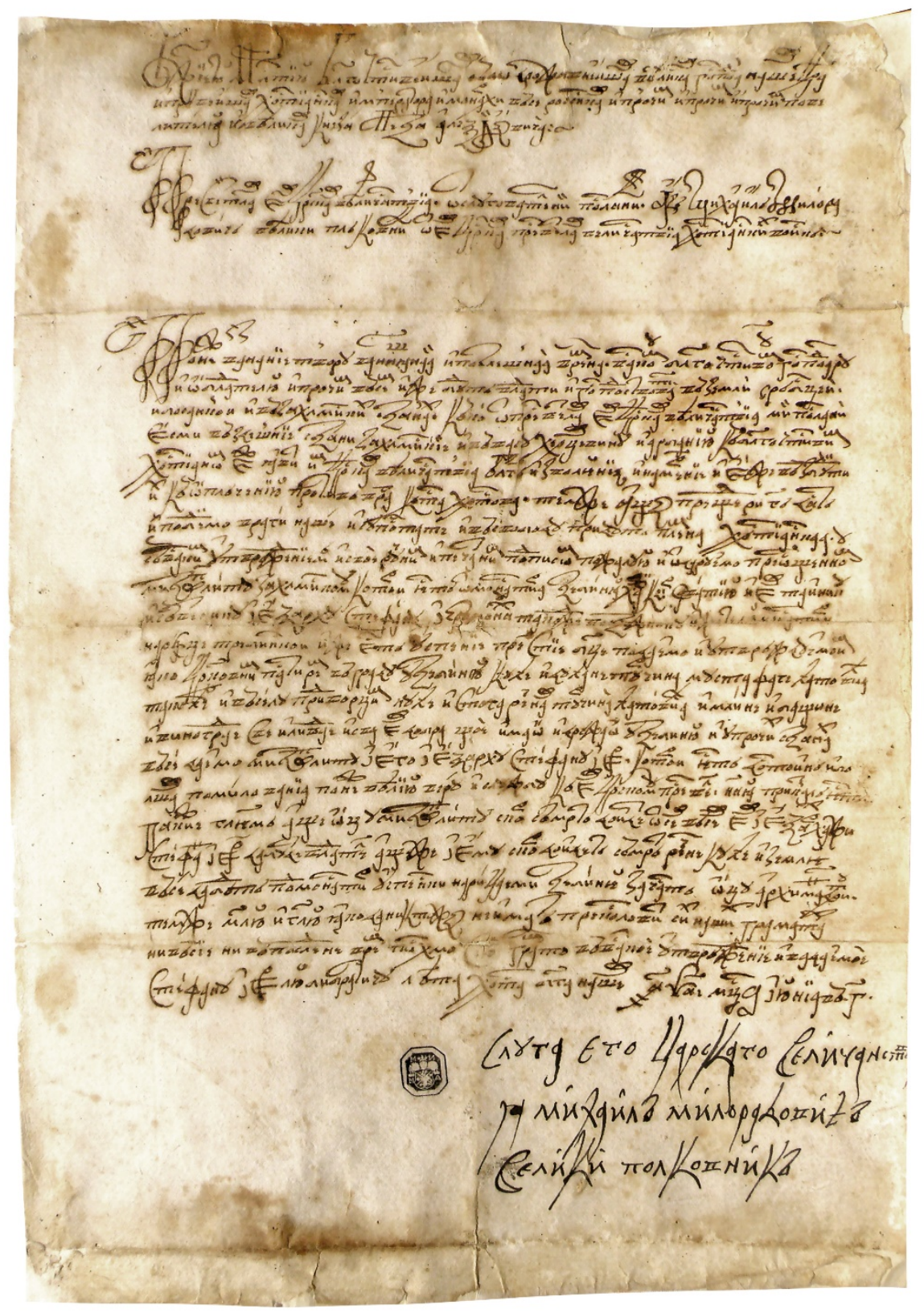

Fig. 2 - Letter of Colonel Mihailo Miloradović (Archive of the Savina Monastery), 1711. 


\title{
MARINA MATIĆ \\ Nezavisni naučni istraživač, Beograd \\ EPISKOP SAVATIJE LJUBIBRATIĆ POD OKRILJEM MLETAČKE REPUBLIKE (1687-1716)
}

\begin{abstract}
Rezime
Delatnost hercegovačkog episkopa Savatija pod Mletačkom republikom bila je uslovljena nizom značajnih događaja izazvanih Morejskim ratom (1684-1699), naročito mletačkim osvajanjem Herceg-Novog od Turaka (1687). Neobjavljena mletačka građa iz više arhiva (Arhiv Herceg-Novog, Arhiv manastira Savina, Državni arhiv Kotora, Arhiv Srpske akademije nauka i umetnosti...) otklonila je nedoumice oko hercegovačkog sedišta episkopa Savatija, koje je, kako smo ustanovili, bilo u manastiru Piva. Posebnu ulogu u rasvetljavanju tog pitanja, uz brojna druga predočena dokumenta, imao je mletački Katastar Herceg-Novog iz 1690. godine, pohranjen u Arhivu Herceg-Novog (Catastico delle terre, case e molini di Castel Nuovo 1990-92, book 2), gde je vladika Savatije, mletački podanik, zaveden kao Vescovo di Piva. Takođe, našim radom preciznije su definisane i brojne aktivnosti episkopa Savatija tokom njegovog obitavanja u Boki Kotorskoj, u periodu od oslobađanja njenog severozapadnog dela od turske okupacije (1684-1687) do vladičine smrti 23. aprila 1716. godine. Tako saznajemo da je on bio velika podrška Mlečanima u naseljavanju strateški važnih pograničnih teritorija u Hercegovini i Boki, ispražnjenih nakon odlaska Turaka. Novim izvorima prošireni su uvidi u Savatijevu ulogu u ratovima, sa posebnim naglaskom na Crnogorskohercegovačkom ustanku iz 1711/1712. godine, u kojem je njegovo posredno delovanje nesumnjivo potvrđeno. Takođe, razmatrana su i nastojanja vladike Savatija da uspostavi episkopsku jurisdikciju za oblasti Dalmacije i Boke, nakon odlaska dalmatinskog episkopa Nikodima Busovića iz Dalmacije na Svetu goru (posle 1702-1703). Sa tim se poklapa i Savatijeva promena u titulaciji, te uz titulu hercegovačkog episkopa od tada nalazimo pridodato i dalmatinski ili primorski. Predočene su i mnoge druge aktivnosti episkopa Savatija pod mletačkim okriljem. Za vreme njegovog stolovanja u HercegNovom oživljen je manastir Savina i izgrađena je Saborna crkva na Toploj. Podsticao je instituciju priložništva, kako bi održao ekonomsku stabilnost crkve, važne tačke oslonca srpskog življa u heterokonfesionalnoj sredini Boke i u datim političkim okolnostima. Veliki je njegov udeo u organizovanju poretka i očuvanju identiteta lokalne srpske pravoslavne zajednice na tim prostorima, pod tuđinskom mletačkom vlašću.
\end{abstract}

Ključne reči: Episkop Savatije Ljubibratić, Piva, Mletačka vlast, pravoslavni identitet, Boka Kotorska, XVII i XVIII vek. 